University of Warwick institutional repository: http://go.warwick.ac.uk/wrap This paper is made available online in accordance with publisher policies. Please scroll down to view the document itself. Please refer to the repository record for this item and our policy information available from the repository home page for further information.

To see the final version of this paper please visit the publisher's website. Access to the published version may require a subscription.

Author(s): Breslin S.

Article Title: Greater China and the political economy of regionalisation Year of publication: 2004

Link to published version: http://dx.doi.org/ 10.1007/s12140-004-0007-x Publisher statement: The original publication is available at www.springerlink.com 


\section{Greater China and the Political Economy of Regionalisation*}

It is not that long ago when the study of China's political economy could all but ignore the external dynamic of the global political economy. But with China's insertion into that global political economy - particularly after Deng Xiaoping's nanxun 南巡 in 1992 - not only has China become embedded in the global, but the global is also increasingly embedding itself in China.

One of the most striking features of this change is the extent to which foreign direct investment (FDI) into China, particularly from Hong Kong and Taiwan, has driven an export boom - an export boom which itself has been the major engine of domestic economic growth in China. In this respect, the term "Greater China” is a useful addition to the lexicon of discourses on understanding economic change in contemporary China. It draws attention to the increasingly transnational nature of economic activity and the disjuncture between national boundaries as the limits of political space ${ }^{1}$.

However, we need to take care about the way we construct a notion of a Greater China economic space to ensure that we do not obscure as much as we elucidate about the dynamics of transnational economic processes. "Greater China” can be both too big and too small. In many cases the term "Greater China” is simply used as a shorthand way of aggregating the economies of mainland China, the two Special Autonomous Regions of Macao and Hong Kong, and Taiwan ${ }^{2}$. But while some areas of the PRC are clearly becoming more closely integrated into the regional and global economy, other areas (and economic sectors) are not. Other understandings of a 
Greater China economic space are too small, in that they try to construct a very narrow conception of regional integration that pays insufficient attention to the role of extra-regional actors and interests, wider processes of East Asian regionalisation, and the significance of globalising processes.

In considering the possible emergence of a Greater China economic space, we need to consider three key characteristics of regionalisation. First, if we retain a geographic focus for regionalisation, then we should not simply think in terms of integration between entire national territories. Across the globe, it is often two or more subnational entities that are becoming integrated - it is not regionalisation but “microregionalisation”3 . Under this understanding, international economic integration and the creation of a transnational regional space can contribute to national economic fragmentation and disjunctures in the national economic space. Second, there are multiple forms of transnational economic spaces that often overlap with each other. Greater China economic regionalisation occurs, and is largely driven by, wider processes of East Asian regionalisation, which themselves interacts with, and are largely driven by, wider global processes.

Third, there is the problem of cartography. By this I refer to understandings of economic space which, whilst trying to move away from the nation state and political boundaries as the basis of analysis, are still based on constructing geographically bound conceptions. The boundaries to economic spaces may no longer be individual national political boundaries, but are instead the cumulative national boundaries of the regional states and territories. Rather than conceive as economic space as nationally 
bound, we can instead conceive of economic spaces that are embedded in "commodity driven production networks"4 that are trans or supranational in nature.

\section{Transnational Economic Spaces: Regionalisation and Regionalism}

The study of regional integration is often predicated on key assumptions about both the processes and outcomes of integrative projects that are not always efficacious for studying East Asia. For example, Balassa’s influential work on economic integration established a model which started from formal co-operation between states followed by the progressive movement towards a free trade area, a customs union, a common market, monetary union and finally total economic integration ${ }^{5}$. It was a predictive model that expects certain formal intergovernmental action before we can say that “economic integration” has occurred.

In addition, the study of regionalism as a sub-set of political economy has been heavily influenced by the European experience - and in many respects too heavily influenced. The construction of a European mode of regional governance after World War Two has become not so much an example of regional construction, but all but the archetypal model against which other regional projects are judged. A number of scholars explicitly took the European experience as a predictor for the future of regionalism elsewhere ${ }^{6}$. Despite the decline in predictive models of regionalism based on the European experience in the mid-1970s ${ }^{7}$, there remains in much scholarship an understanding that regionalism will entail at least some of the institutionalisation exhibited in the European model, and there is often an implicit understanding that something like the European Union will be the end point of integrative processes ${ }^{8}$. 
This emphasis on intergovernmentalism as the main dynamic behind interpretations of processes of regional integration frustrated those who argued that real economic integration was occurring across national political boundaries where there was no formal intergovernmental agreement or institutionalisation - processes that were not captured by statist top down definitions of regionalism. As such, a common theme in the expanding literature on "new regionalism" is the need to distinguish between the different types of regional processes. Thus, “regionalism” has widely become accepted to refer to the conscious and deliberate attempts by national states to create formal mechanisms for dealing with common transnational issues through intergovernmental dialogue and treaty. By contrast, "regionalisation” thus conceived as an undirected process of growing interdependence which originates in the actions of individuals, groups and corporations rather than through the deliberate actions of national governments ${ }^{9}$. While accepting that governments and intergovernmental dialogue remain important, the emphasis here is on other actors and other forms of interaction across national political borders that tie people and economies together.

These two types of processes are not necessarily mutually exclusive. Indeed, some theorists see regionalism as a response to regionalisation. Neofunctionalists and neoliberal institutionalists share a conviction that as economic activity becomes more international, states co-operate to find regional solutions to common problems. While this may originally take the form of informal or ad hoc co-operation, they typically become formalised in regional organisations. Neofunctionalists argue that while such co-operation usually originates in the economic sphere, it will eventually "spillover" into other forms of joint political co-operation, and eventually to political integration and the transcendence of the state. Thus, political integration can be seen as the 
unintentional consequence of a number of smaller economic decisions by non-state actors $^{10}$.

But while an emphasis on regionalisation might, from some perspectives, be the precursor to the establishment of formal regionalism, there is no assumption in the literature of "new regionalisms" of convergence towards a final form of regional governance. Rather there is an acceptance of diversity. As Smart argues:

“capitalist practices are embedded in local structures, and that certain contexts can generate new and vibrant variations upon the theme of capitalism. If nothing else, globalization produces a considerably diverse set of local outcomes"11

Thus, we should expect increased economic interaction to produce a variety of different processes of regional economic integration - not all of which will lead to formal regionalism.

Indeed, for those who point to the importance of the deterritorialisation of production, there is little or no evidence to suggest that regionalisation will lead to regionalism. For many, the key to understanding globalisation is a knowledge of "post-Taylorist 'flexible’,12 approaches to the organization of production within and between firms. 'capitalism today...entails the detailed disaggregation of stages of production and consumption across national boundaries, under the organizational structure of densely networked firms or enterprises' ${ }^{13}$

While the international economy of the Bretton Woods era characterised by exchange relations between national economies, the new political economy is grounded in: 
'the structural power of internationally mobile capital. States now have to recognise the power not only of other states and international organisations .... but also of international capital, the banks, and foreign exchange markets. ${ }^{14}$

We need to take care not to just explain regionalisation as simply an economic process. For example, in the extreme "hyper-globalisation" thesis of Kenichi Ohmae, the role and significance of the state and state actors in the creation of what he terms "region states" is essentially ignored. The significance of state borders is also, at the very least, downgraded:

"What defines [region states] is not the location of their political borders but the fact that they are the right size and scale to be the true, natural business units in today's global economy.” 15

It is true that that the investment decisions of corporations and the mobility of capital has been the major dynamic for regionalisation. Rising manufacturing costs in the region led producers to shift capital out of the original regional developmental states into a new cheaper production site - China. But while non-sate actors play a dominant role in shaping financial and commodity flows, so to do states and state actors who facilitate the spread of global finance and production.

Special Economic Zones (SEZs) do not create themselves; taxes are not lowered (or removed) on their own; and money can only be freely exchanged across national political borders if governments allow it (well, legally at least). Neither do ports, roads and railways build themselves - as the German Budestag report on globalization forcefully argued, the hard infrastructure that is so necessary for the physical 
transportation of goods is usually funded by governments rather than by the private sector and:

'The growing worldwide integration of economies came not by any law of nature - it has been the result of active and deliberate policies'. ${ }^{16}$

Policies designed to facilitate interaction with the global economy are predicated on a prior ideational choice that participation in the global economy is beneficial to perceived interests. In the Chinese case, the interests of key party-state elites lay in generating growth to provide an economic basis for legitimising continued communist party rule. As with many other developing countries, the best way of ensuring this growth was increasingly seen as achieving rapid capital accumulation through insertion into the capitalist global economy. There is thus and ideational acceptance, albeit not necessarily explicitly stated, that dependence on the capitalist global economy is the best or at least the quickest way of promoting economic growth. So while the actions of external non-state actors have played a significant role in the reconfiguration of economic space, we should be careful not to relegate the state to a passive or even irrelevant role. The state acts as a facilitator of non-state economic flows, establishing the environment in which the market can function.

\section{Great China and Regionalisation}

Intra-regional FDI

The prima facie evidence for the existence of a Greater China economic space is built on the extent of non-PRC Chinese investment in the PRC, and the importance of PRC trade with other Chinese states/territories. Perhaps the most compelling case for the existence of a Greater China economic space arises from an analysis of the growth 
and extent of investment from Hong Kong, Macao and Taiwan into China. Houde and Lee calculate that between 1993 and 1998, Hong Kong provided over half of all investment into China, Taiwan nearly eight per cent, and Singapore around 4.5 per cent $^{17}$. Deploying an ethnicity rather than nation centred approach, Charles Wolf calculates that "two-thirds [of all investment has] come from "overseas" Chinese, especially overseas Chinese in Taiwan, Hong Kong, and Southeast Asia.”18 . If we add in investment from Japan, then the figure for Asia as a whole rises to nearly 80 per cent, with Europe and North America each accounting for between seven and nine per cent depending on which figures are used.

When assessing all things related to the Chinese economy, we need to insert a caveat over the reliability of Chinese statistics. Of particular relevance here is the practice of routing domestic PRC investment through Hong Kong in order to take advantage of incentives for foreign investors. This practice allows PRC investors to gain tax exemptions on initial profits, and on imported machinery and components. It also provides a means of bypassing restrictions on currency conversion and capital flight through the practice of overcharging for imported materials. It is difficult to estimate the full extent of this practice - its illegality is not exactly conducive to transparency, though a figure of around 14 per cent of all investment from Hong Kong is not generally challenged ${ }^{19}$.

More recent figures on investment suggest a relative decline in the importance of investment from Hong Kong and Taiwan. This is partly due to the rise of investment from the USA in the wake of China's entry into the WTO in 2001. It is also partly a result of a rush by South Korean companies to move large parts of their 
manufacturing capacity to China in 2003. More important is the astonishing rise of investment from Latin America. Almost all of this Latin American investment comes from the British Virgin Islands, (now the second largest investor in China) and the Cayman Islands (now eighth). The explanation for this rise in investment is found in the fiscal regimes of the Virgin and Cayman Islands. Investors from other countries notably Hong Kong and Taiwan - incorporate in these tax havens in order to lower (or eliminate) their fiscal commitments ${ }^{20}$.

The very nature of this type of investment makes it difficult to know where it originates. Wu et al point to the significance of Hong Kong companies, noting a fivefold increase in the number of Hong Kong companies incorporating in Bermuda in a decade ${ }^{21}$. Other data, supported by interviews in the region, emphasises the role of Taiwanese firms - partly to take advantage of the tax regime, but also to bypass Taiwanese government restrictions on investment in the mainland. After China, the British Virgin Islands and Cayman Islands rank second and third respectively as the biggest recipients of Taiwanese outward investment ${ }^{22}$. As such, although official figures show a decline in the importance of Chinese investment into China since 1998, this appears to have more to do with methods of identifying the nationality of investment, rather than a real decline in investment led regionalisation.

\section{Intra-regional trade}

An assessment of trade patterns might lead to similar conclusions about greater China economic integration. Though here too we face problems in interpreting statistics due to the special role of Hong Kong in Chinese trade. Prior to the start of the reform process in 1978, Hong Kong provided China's main link with the global economy, 
acting as a transit point for exports and imports with the capitalist world. As China has established more and more bilateral economic relations with other countries, we might expect the importance of Hong Kong to decline. But China's special relationship with Hong Kong has remained intact.

Trade between China and Hong Kong is now the world's third biggest bilateral trade relationship (behind US-Canada and US-Japan trade) ${ }^{23}$. Furthermore, the percentage of Chinese exports to Hong Kong which are subsequently re-exported to other destinations has actually increased, and Hanson and Feenstra calculate that between 1988 and 1998, just over half of all Chinese exports were routed through Hong Kong $^{24}$. So while an initially glance at direction of trade statistics suggests that Hong Kong is a major consumer of Chinese exports, the reality is that the overwhelming majority of these exports subsequently end up elsewhere - predominantly in the US, the EU, and Japan.

The real significance of trade for regional integration is in China's position as a recipient of imports from Taiwan and Hong Kong. This is in no small part due to the migration of Hong Kong's manufacturing industries over the border into China. Facing rising land and labour costs, Hong Kong producers have simply moved production over the border into China is a similar way to which maquiladora factories developed in Mexico through the migration of US companies. In both examples, the core urban sector has essentially extended its economic influence over the national political border - hence the process is sometimes simply referred to as "metropolitan spillover” or as “extended metropolis” 25 . In effect, components are exported into China from Hong Kong, and the finished produce then re-exported out through Hong 
Kong to markets in the developed world - as Berger and Lester argue, the goods are made in China, but made by Hong Kong ${ }^{26}$.

As Taiwanese firms subsequently moved much of their productive capacity to China, this similarly generated a wave of exports to China in the form of components used to manufacture finished goods to markets in third countries. What this suggests, then, is the emergence of a region of production built on a dense network of investment generated trade relationships. But crucially, it is a process of integration that has far from impacted on all of China, and one that is predicated on wider global processes, and extra-regional actors and interests.

\section{Great China and Microregional Integration}

The majority of work on regionalisms new and old concentrates on relationships between two or more nation states. However, largely inspired by the work of political and economic geographers ${ }^{27}$, there is a strand of literature in international political economy that points to the importance of moving away from national conceptions. Rather, it argues that much of the real integration that is taking place - primarily economic integration - takes place below the national level ${ }^{28}$.

Such sub-national cross-national regional integration can take the form of formal regional agreements - for example, the growth triangles that have been a formal part of region building within ASEAN since $1992^{29}$. At the risk of oversimplification, we can identify three main reasons for the establishment of these regions. The first is the desire to exploit economic complementarity. An example here would be the development of the Tumen River Delta project. National and local state leaders ${ }^{30}$ are 
attempting to build a region that can exploit the capital and technology of Japan and South Korea; the natural resources of the Russian far east (and potentially North Korea); and the abundant (and cheap) labour, land and primary resources in northeastern China.

The second is where sub-regional growth areas are proposed and created to facilitate resource pooling, and/or the joint development of natural resources, infrastructure, and industries in cases where the resources are located on or around the international border. A good example is the Malaysia-Thailand Joint Development Area to explore and transport offshore natural gas to Songkhla in southern Thailand for onward redistribution to each country's market. In such cases, the initiatives stem from sharing capital investment, and potentially also from resolving territorial disputes (particularly in the case of off-shore resources).

The third is where neighbouring local authorities deem that local collective action is the most efficient mechanism of dealing with local transboundary issues. Morata's analysis of North-West Mediterranean Euroregion provides a good example here ${ }^{31}$. Established by the Presidents of Catalonia, Lanquedoc-Roussillon and Midi-Pyrenees, Morata argues that sub-regionalism was driven by the development of wider European integration. In essence, the authority and efficacy of national governments in dealing with transboundary issues has been undermined by both the transfer of some fields of national sovereignty upwards to the EU and the concomitant dismantling of national borders as barriers to inter-EU trade. Institutional changes at the EU level, as well as new communication technologies and the development of transportation, have encouraged the formation of regional networks based on common 
interests in terms of economic development. Microregionalism, then, not only coexists with other forms of regionalism and globalization, it is inextricably linked to them.

The link between the microregion and globalization is perhaps even clearer when it comes to microregionalisation. Here, there is no formal agreement and no formal conception of the borders and parameters of microregional integration. But the level of economic interaction is so great that a new economic space is created that spans national political borders. And of course, given the political difficulties that make intergovernmental dialogue between China and Taiwan so problematic, it is microregionalisation that is most germane to this study.

For China watchers, the need to disaggregate the Chinese economy to take into account regional variations is now almost taken for granted. There is now a relatively large literature on the relationship between central and local authorities in China. Chung's "mid term appraisal” of centre local relations in 1995 showed work on centre-local relations already constituted a sizeable and growing sub-field within Chinese studies $^{32}$. Not surprisingly, this canon of work has undergone substantial growth in the subsequent years, including the establishment of the journal "Provincial China” in recognition of the diverse nature of politics and society beneath the national level. Although Lynne T White $(1998,1999)$ rebuked the mainstream "centralist" literature on China in his study of Shanghai ${ }^{33}$, the idea that the study of China's political economy must look at what happens at the sub-state level is now all but firmly accepted by scholars of contemporary China. 
A key consideration in this literature is the differential wealth of China's provinces. And here, the ability to attract foreign investment - to engage with the global economy - is particularly important. Almost 90 per cent of cumulative FDI since 1978 has gone to coastal provinces from Zhuhai in the south to the Liaodong peninsular in the north. Indeed, statistics from MOFTEC show that FDI in Guangdong, Jiangsu and Shanghai alone accounted for roughly half the national total in 2000. Guangdong Province has been the single biggest recipient, though its share of investment has declined as more FDI has moved to other coastal areas such as Shanghai and Liaoning ${ }^{34}$. Nevertheless, Guangdong, or more correctly, the Pearl River Delta, remains a major site for FDI. Only four provinces (Shanghai, Jiangsu, Fujian, and Shandong - plus of course, Guangdong itself) received more FDI than Shenzhen alone. This uneven share of provincial FDI is also reflected in the uneven distribution of exports from Foreign Invested Enterprises (FIEs), with eight coastal provinces accounting for 95 per cent of all FIE exports. When you add on trade by companies working on contracts for foreign companies, then getting on for 75 per cent of all trade in these coastal provinces is carried out either by or for external companies.

Typically, the value added within China is relatively low in these export oriented FIEs. In an early work on FDI in China, Lardy calculated that imported components typically accounted for 90 per cent of the value of exports from FIEs ${ }^{35}$. In 2000, the value of imports of foreign invested enterprises was 98 per cent of the value of exports - indeed, 1998 was the first year that the value of exports from FIEs actually surpassed the value of their imports - though this is a very rough indicator as it 
includes all imports, not just those used to produce exports. If we just look at the processing trade alone, then the figures show that imports accounted for 86.5 per cent of the value of FIE processing trade exports in $2000^{36}$.

What this means is that there are very low levels of integration between these FIEs and the domestic Chinese economy. They utilise domestic energy, land and labour, but very little else. Just as Bernard and Ravenhill suggested that export processing zones in Malaysia were “more integrated with Singapore’s free-trade industrial sector than with the 'local' industry”37, so China's FIEs are physically located in China, but economically perhaps form part of an economic space that is not territorially bound.

So the concept of Great China as micregion does have validity as an explanatory took for understanding the relationship between international economic integration and national economic fragmentation. But even here there is a problem as there are low levels of integration between different internationally integrated parts of China - they are perhaps more integrated with the external than they are with themselves.

So in many respects, it makes less sense to talk about a geographically defined microregion of Greater China than concentrating on the individual manifestations of microregions - most obviously between Hong Kong and the Pearl River Delta ${ }^{38}$. If there is a single economic space in which Taiwan, Hong Kong and southern China are becoming economically integrated, it is a "hub and spoke" economic space centred on Hong Kong, with very weak levels of horizontal integration on the PRC side. Rather than talk in terms of one single economic space, or one single process of regional 
integration, perhaps it is wiser to refer to or multiple processes and overlapping mcroregionalisation processes.

Or perhaps we should put cartography aside, and think of integration in different terms. While local authorities across China may compete with each other to attract investment, policy is based in a shared conception of the benefits of engaging with the global economy. Specific policies may be confrontational, but there is an increasing ideational conformity. Or perhaps we should throw away conceptions of the nation state, and instead think of economic spaces that are located within production networks. If we do, then we can see that the processes of regional economic integration that is taking place within Greater China is in large part dependent on wider global process of economic change.

\section{Greater China, East Asia and Globalisation}

We noted above that much of what is produced through investment in China is exported to the major markets of the industrialised world - primarily North America, Japan and the European Union. Already we see here a key link between regional and global processes - if Greater China is a region of production, then this production remains largely contingent on consumer demand outside the region. But there is another dynamic here as much of the investment itself has its roots outside the region.

As Bernard and Ravenhill ${ }^{39}$, Crone ${ }^{40}$, and perhaps most forcefully, Hatch and Yamamura $^{41}$, have argued, many Taiwanese and Hong Kong Asian producers are tied into a position of "technological dependence" on Japan. As such, the suggestion is that investments into the PRC by Hong Kong and Taiwanese investors have more to 
do with Japan's "network power" ${ }^{42}$ than appears at first sight. The investment into and trade with China might not be through Greater China, but it is Japanese companies that "cause" this investment and trade ${ }^{43}$. Furthermore, many Japanese companies still run their investment projects in China via regional offices based in Hong Kong. The use of subsidiaries in Hong Kong is a particularly important element in Japanese investment in southern China. Although sorting through the statistics is an inexact science, Matsuzaki has estimated that about 80 per cent of Japanese FDI in Hong Kong is subsequently reinvested in Guangdong ${ }^{44}$. The original investment into Hong Kong will appear as originating in Japan, but when it is subsequently reinvested into China, it will appear as Hong Kong investment, thus providing more statistics to support the case for economic integration and even microregional integration in Greater China.

When we add this to direct Sino-Japanese trade and direct Japanese FDI into China, then the case for a Greater-China economic space, rather than a wider Japan-centred regionalisation process, appears to diminish in force. At the very least, Greater Chinese regional integration should be viewed in the light of wider regional processes.

But it is not just Japan that provides a disguised extra-regional source of investment. By considering Original Equipment Manufacturing (OEM), investment into China by extra-regional actors located within the region, and the growth of Contract Manufacturing Enterprises (CMEs), we can see that a tight insular conception of Greater China misses the huge significance that extra-regional actors play in fostering regional integration. 
OEM production occurs where a company allows its products to be used in the production of other companies' goods. This might entail the final producer utilising technology or components under the original providers name - for example, the use of Windows and Intel in many personal computers - or putting their own name on components under licensing agreements with the original provider. OEM production is particularly important in the computer industry. Around 70 per cent of all computer related goods produced by Taiwanese firms are based on OEM contracts with foreign firms - primarily from the US and $\operatorname{Japan}^{45}$. This is partly a result of changes in industrial strategy in the US electronics industry. While US IT producer tried to compete with Asian companies in the 1980s, they instead moved to create network relationships with those producers in the 1990s. The US companies concentrated on producing software and hi-tech essential components, leaving the production of the computers themselves to Asian partners ${ }^{46}$.

Taiwanese computer companies in particularly actively embraced this changing production structure locating themselves as key links in the production chain. OEM agreements with US and Japanese companies allow them to utilise foreign technology and operating platforms in their computers - computers that are increasingly assembled in low cost factories in China to maintain cost efficiency. Indeed, nearly three quarters of China's computer related products are produced by Taiwanese companies, which are themselves dependent on OEM contracts with Japanese and US companies $^{47}$. It is particularly important in for three localities in China, where Taiwanese computer companies have agglomerated - Dongguan in Guangdong Province, Suzhou in Jiangsu and Shanghai. As such, these Taiwanese invested 
factories in China represent the end stage of a production process that spans the most industrialized global economies such as the USA and Japan, intermediate states such as Taiwan, and developing states like China. And of course, most of the finished goods are then sold outside the Greater China region as well.

A second form of extra-regional involvement in Greater China integration is foreign indirect investment takes place through subsidiary offices within East Asia, and in particular in Hong Kong. As of 1 June 2002, Hong Kong was the host to 3,119 overseas companies' regional offices or headquarters, and a further 1,230 local offices. Although Japanese companies are the largest representatives (471), US companies come a close second (437) ${ }^{48}$. Of course, not all of these companies are in Hong Kong just to access China, and not all of them will be sources of "Hong Kong” investment. Indeed, it is all but impossible to calculate the extent to which investment in China from Hong Kong originates from these regional offices of foreign companies. Perhaps the best we can say is that Hong Kong remains an important platform for third party investment into China which is not revealed by looking at the official investment statistics.

It becomes even more difficult to calculate the real extent of non-Chinese investment in China when we consider the extent of sub-contracted FDI. Here, third country investors do not directly invest in China either directly or through regional offices, but instead sub-contract production to investment companies within the Greater China region itself. Such investment has been a major element in western companies involvement in China in textiles, clothing and shoes, toys, and more recently, electronics. There have been a number of studies that trace such indirect investment in 
specific case studies. Perhaps the most famous in the Pou Chen company in Taiwan, which produces one in eight of all the world's sports shoes in factories in China on behalf of Nike, Reebok, New Balance, Adidas, Timberland, Asics, Puma, Hi-Tec, Lotto, LA Gear, Mitre and so on ${ }^{49}$. A similar example of how Mattell produced Barbie dolls in China via a Taiwanese intermediary, first aired in the Los Angeles Times ${ }^{50}$, subsequently had the honour of being used in the State Council White Paper on the Sino-US trade imbalance ${ }^{51}$.

In all the above cases, third party companies have sub-contracted to regional intermediaries that have then invested in China - often in joint ventures, though wholly foreign owned enterprises are now the investment project of choice. In these cases, investment figures for China will show a transfer from the intermediary company's country, and not from the original investor country. A second type of subcontracting is where the third country company sub-contracts to a regional intermediary, which then produces in China on a contract basis. In these cases, no investment will be recorded as the transactions are on a processing fee basis, even further disguising the original investors’ involvement in the Chinese economy.

Major investment companies such as the Swire Group and the Jardine Matheson Group have long acted as intermediaries between China and the global economy. There are also a plethora of locally owned contract manufacturers in Greater China, such as Li and Fung in Hong Kong and Hon Hai Precision in Taiwan ${ }^{52}$. There are three main reasons why these intermediary companies have established themselves as a link between foreign producers and China. First, Rodrik has noted a tendency to sub-contract to countries with poor labour standards rather than invest there directly ${ }^{53}$. 
This assertion is supported by interviews in Hong Kong. Certain US based companies, use sub-contracting through Hong Kong because they fear that being associated with sweat-shop production would severely damage their image (and therefore sales) at home. They can genuinely argue that they don't invest in sweat-shops - but it does not necessarily mean that products carrying their brand names are not produced in sweat shops.

Second, the intermediary companies market themselves as matchmakers with specialist knowledge of China. They have the linguistic skills, they know the culture, and they have the personal contacts that are so important for doing business in China $^{54}$. In many respects, they exploit the idea that doing business in China is best left to the Chinese themselves, and that only those within Greater China can really understand Greater China.

This type of production process is referred to as "demand-responsive reflexive" 55 . In real words, this means that major corporations do not have to worry about maintaining factories staffed by workers who will not only require higher wages than need to be paid in China, but also welfare contributions and redundancy payments if production is cut back during times of slack demand. Indeed, an increasing number of major multinational companies simply do not produce anything themselves anymore focussing on establishing brand names through PR and marketing ${ }^{56}$. Even research and development is now frequently devolved to contract manufacturers like Flextronics, which operates out of Singapore and invests in China for a host of major global IT producers. And while such outsourcing through contract manufacturing has 
long been a feature of the textile and apparel industries, it is growing ever more significant in the IT industry, growing at 20 to 25 per cent per annum ${ }^{57}$.

As China has become the "world's outsourcer of first resort" 58 , it has become engaged in this global division of production - typically at the low tech and low value added processing stage. In all these cases, the 'Made in China' brand will appear on the good - a good which carries a non-Chinese brand name. Investment and trade figures will show integration in Greater China through increased trade and investment flows. But the originators of this investment and the consumers of the finished good often lie outside the region. Our understanding of the implications of international economic flows are still often based on studying bilateral figures. But as economic activity is not restrained by bilateral relationships between nation states, such a focus will only at best give us a partial idea of where the real dynamics lie in the global political economy.

\section{Whose Region?}

There is a general tendency to assume that regional integration is a positive thing. Welfare gains are typically forecast through the reduction of transaction costs, the exploitation of economic complementarity and the creation of integrated markets. While this assumption is more applicable to formal regionalism rather than regionalisation, there is still a largely positive economic conception of integration not least through the transfer of technology and expertise from cores to peripheries. Socially, integration is predicted to break down barriers between peoples through greater people-to-people transactions. And politically, by coming together to deal with 
common issues, governments are predicted to establish mutual understanding and trust with each other.

Assessing the social and political spillovers of Greater China economic integration provides a rather mixed picture. In terms of China-Taiwan relations, a strong argument can be made for suggesting that economic integration has established the basis for a more peaceful relationship. Given that the economic fortunes of the PRC are heavily influenced by the investment decisions of Taiwanese businessmen, instability in the region (not to mention war) would have a disastrous impact on the domestic Chinese economy.

The flip side of this coin is that there is concern within Taiwan that the extent of investment on the mainland makes the Taiwan's economic fortuned dependent on what happens in the mainland. Despite introducing policies aimed at slowing rates of investment to China, and attempting to divert investment to South East Asia, successive Taiwanese governments have been unable to control the investment decisions of domestic companies. The view from that side of the Straits is that it is Taiwan that is dependent on China, not the other way round, generating fears that the mainland will be able hold Taiwan's economy to ransom if Taiwan pushes for independence and/or international recognition as a state.

The economic picture is also not wholly clear cut. With the exception of 2001, Taiwan's GDP has continued to grow as investment and manufacturing have moved to China since the first year of large scale investment in 1993. But at the same time, the unemployment rate has continued to rise from $1.45 \%$ in 1993 to $5.17 \%$ in 2002 
before dropping back to just under five per cent in 2003. Similarly, with the exception of 1998, Hong Kong's GDP has also continued to grow. A growth rate of over 3 per cent in 2003 might be modest by historical comparison, but is still a growth rate that managers of most economies in the developed world would be more than pleased with. But as with Taiwan, unemployment rates have also risen, from two per cent in 1993 to almost eight per cent in 2003.

Although growing unemployment rates cannot all be blamed on the transfer of manufacturing jobs to China - the growing number of women in the workforce in Hong Kong being an important case in point. But economic integration built on investment and trade to produce exports to third markets does in part explain why Taiwan and Hong Kong have witnessed overall growth combined with growing unemployment and low or even negative growth in domestic demand. The outsourcing of production to produce exports needs neither domestic workers, not the domestic market in order to generate corporate profits and overall national growth.

So economic growth that has been achieved in Hong Kong and Taiwan through integration with the Chinese economy has been largely jobless growth. Whether regionalisation is a good thing or not depends. For business interests provided with an opportunity to reduce manufacturing costs and increase profits, it is a very good thing indeed. For workers, particularly low skilled labourers, it is a very different matter.

\section{$\underline{\text { Conclusions }}$}

This paper has assessed the notion of a Greater China economic space in light of three approaches to understanding international political economy. The first is sub-regional 
integration. This approach maintains a strong notion of geography and territory, and is most useful in leading towards an understanding of the processes involved in regional integration. In particular, it suggests that sub-regional integration is built on unequal levels of development. It also draws attention to the relationship between governmental decisions, and the investment decisions of non-state actors (between top down and bottom up regional processes).

Furthermore, it is an approach which stresses the importance of limiting the geographic scope of our investigation regional integration (on the PRC side at least). We need to focus on which parts of China are becoming integrated into a Greater China economic space, and perhaps subsequently the implications for governance in China of an emergent dualistic economy.

While it is correct to look for perspectives that move away from traditional state centred notions of economic "space" or "territory", in doing so we should not simply create new notions of space that are equally constrained by ideas of boundaries - even if these are not state boundaries. When we question the porous nature of state borders and boundaries, we should be careful in finding new ways of re-drawing borders and boundaries. Even one of the architects of the "hyper-globalisation” thesis, Kenichi Ohmae falls into this trap. Ohmae argues that maps obstruct our understanding of how the global economy works by placing political boundaries in the way of perceptions of economic activity ${ }^{59}$. Yet he too relies on cartography as the boundaries of his “region states" are drawn around geographically proximate territories - they are still geographically conceived. 
Thus, following Bernard ${ }^{60}$ and others, we can follow a network-centred approach which, drawing us even further away from the map than Ohmae, conceptualises a more complex structure built on buyer commodity driven chains of decentralised production networks ${ }^{61}$. At the very least, it forces us to think of the relationship between regional integration and globalisation, with the suggestion here that the latter has in many ways configured the former.

What might be called a "Coxian" approach ${ }^{62}$ also draws us away from notions of territory and instead emphasises the importance of collaboration between transnational economic elites. As with the network approach, it stresses the importance of extra-regional economic elites, and suggests an uneven societal (rather than geographic) notion of integration - integration is for the elites not the masses (and often at the expense of the masses).

It is not my intention to deny the existence of regional integration. Rather, I suggest that in assessing the notion of a Greater China economic space, we need to consider two key issues. First, regional and global processes should be considered in tandem. Indeed, the epistemologies deployed in this paper suggest that globalising forces have been key determinants of Greater China sub-regional integration. They also suggest that the major drivers of the global economy in the developed world - or perhaps more correctly, investors and consumers in the developed world - are key determinants of greater Chinese sub-regional integration. Second, we need to think about what regional integration really means - who is being integrated with who, for whose benefit, and with what implications for policy making and the establishment of effective economic governance in individual regional states? 
This paper was concluded while I was Visiting Professor in the Department of Applied Social Studies at City University of Hong Kong, and I gratefully acknowledge CityU's support. The concept of "nation" is, of course, somewhat problematic in the Chinese case given the special position of the Special Administrative Regions and the contested status of Taiwan. For example, see Taylor, R (1996) Greater China and Japan: Prospects for an Economic Partnership in East Asia (Routledge: London). Breslin, S. and Hook, G. (eds) (2002) Microregionalism and Word Order (Basingstoke: Palgrave).

G. Gereffi, M. Korzeniewicz, and R. P. Korzeniewicz, "Introduction: Global Commodity Chains”, in G. Gereffi and M Korzeniewicz, eds., Commodity Chains and Global Capitalism, (London: Praeger, 1994). Balassa, B. (1962) The Theory of Economic Integration (London: Allen and Unwin). See, for example, Lindberg and Scheingold, S.A. (1970) Europe's Would-be Polity: Pattens of Change in the European Community (Engelwood Cliffs, NJ: Prentice Hall), Schmitter, P.C. (1971) 'A Revised Theory of European Integration', in L.N. Lindberg, L.N. and Scheingold, S.A. (eds) Regional Integration: Theory and Research (Cambridge, MA: Harvard University Press) and Nye, J.S. (1968) 'Comparative Regional Integration: Concept and Measurement', International Organization 22 (4). Not least because of the publication of Haas, E.B. (1975) The Obsolescence of Regional Integration Theory, Berkeley: Institute of International Studies Working Paper.

Breslin, S. and Higgott, R. (2000) "Studying Regions: Assessing the New, Learning from the Old” in New Political Economy Vol 5 No 3 November 2000 pp. 333-353.

Gamble, A. and Payne, A. "Conclusion: The New Regionalism" in Andrew Gamble and Anthony Payne (eds) Regionalism and World Order, (Basingstoke: Macmillan, 19960: 250. Hurrell, A. (1995) "Explaining the Resurgence of Regionalism in World Politics" Review of International Studies 21 (4): 348-9.

Smart, A. (2000) "The Emergence of Local Capitalisms in China: Overseas Chinese Investment and Pattern of Development” in Si-Ming Li and Wing-Shing Tang (eds) China's Regions, Polity, \& Economy: A Study of Spatial Transformation in the Post-Reform Era, (Hong Kong: University of Hong Kong Press) : 64. Ngaire Woods (eds) Inequality, Globalisation and World Politics, (Oxford: Oxford University Press) : 36-65.

Gereffi, G., Korzeniewicz, M., and Korzeniewicz, R. (1984) "Introduction: Global Commodity Chains", in Gary Gereffi and Miguel Korzeniewicz, (eds.) Commodity Chains and Global Capitalism (London: Praeger) : 1 .

Payne, A. and Gamble, A. (1996) "Introduction: The Political Economy of Regionalism and World Order" in Andrew Gamble and Tony Payne (eds) Regionalism and World Order (Basingstoke: Macmillan) :15. German Bundestag Study Commission (Select Committee), Globalisation of the World Economy - Challenges and Responses (2001) http://www.bundestag.de/gremien/welt/welt_zwischenbericht/zwb003_vorw_einl_engl.pdf Houde, Marie-France and Lee, Hak-Loh (2000) "Main Determinants And Impacts Of Foreign Direct Investment On China’s Economy” OECD Working Papers On International Investment Number 2000/4: 7.

Wolf, Charles (2002) Straddling Economics and Politics: Cross-Cutting Issues in Asia, the United States, and the Global Economy (Santa Monica, CA: Rand Corporation) :134 Though one ex European Commission official suggested that DG2 considers that it might be as high as 40 per cent. Palan, R. (2002) "Tax Havens and the Commercialisation of State Sovereignty", International Organization 56 (1) (2002): 152.

Wu, F., Poa Tiong Siaw, Yeo Han Sia and Puah Kok Keong (2002) "Foreign Direct Investments to China and Southeast Asia: Has Asean Been Losing Out?” in Economic Survey of Singapore (Third Quarter): 102. 
It is instructive that British Virgin Isles are now the largest source of inward investment into Taiwan itself. As foreign companies pay lower corporate tax rates in Taiwan than domestic firms, it appears that, as with China, there is considerable recycling of investment in Taiwan. Dale, H (1997) "The Economic Integration of Greater South China: the Case of Hong-Kong Guangdong Province Trade” in J Chai, Y Y Kueh, and C Tisdell eds China and the Asia Pacific Economy (Commack, NY: Nova Science) p.76.

Hanson, G and Feenstra, R (2001) “Intermediaries in Entrepôt Trade: Hong Kong Re-Exports of Chinese Goods” NBER Working Paper 8088: 2.

Chia Siow Yue and Lee Tsao Yuan (1993) "Subregional Economic Zones: A New Motive Force in Asia-Pacific Development” in Fred Bergstein and Marcus Noland (eds) Pacific Dynamism and the International Economic System, (Washington: Institute for International Economics) : 236.

Berger, S. and Lester, R. (1997), Made by Hong Kong, (Oxford: Oxford University Press).

For example Anderson J. and O’Dowd, L. (1999) "Border, Border Regions and Territoriality: Contradictory Meanings, Changing Significance” Regional Studies, 33 (7): 593-604; Storper, M. (1997) The Regional World: Territorial Development in a Global Economy, (New York: The Guilford Press); and Scott, A. (2000) Regions and the World Economy: The Coming Shape of Global Production, Competition, and Political Order (New York: Oxford University Press).

For example, Perkmann, M. and Sum, N. (eds) (2002) Globalization, Regionalization and Cross-Border Regions (Basingstoke: Palgrave) and Breslin, S. and Hook, G. (eds) (2002) Microregionalism and Word Order (Basingstoke: Palgrave).

Chia Siow Yue and Lee Tsao Yuan (1993) "Subregional Economic Zones: A New Motive Force in Asia-Pacific Development” in Fred Bergstein and Marcus Noland (eds) Pacific Dynamism and the International Economic System (Washington: Institute for International Economics): 230.

With the aid and support of the UNDEP.

Morata, F (1997) “The Euro-region and the C-6 Network: The New Politics of Sub-national Cooperation in the West-Mediterranean Area” in Michael Keating and John Loughlin (eds.) The Political Economy of Regionalism (London: Frank Cass) : 292-3.

Chung, Jae Ho (1995) "Studies of Central-Provincial Relations in the People's Republic of China: a Mid-Term Appraisal” China Quarterly December: 487-508.

White, L (1998) Unstately Power: Volume 1, Local Causes of China's Economic Reforms (Armonk, NY: M.E. Sharpe) and White, L. (1999) Unstately Power: Volume 2, Local Causes of China's Intellectual, Legal, and Governmental Reforms (Armonk, NY: M.E. Sharpe). 58 per cent of all FDI in Liaoning goes to Dalian Municipality. Lardy, N. (1994) China and the World Economy, (Washington: Institute for International Economics). This may partly be explained by transfer pricing. Despite considerable liberalisation in China, many foreign companies still face problems in repatriating profits due to incomplete currency convertibility and the imposition of myriad ad hoc charges on the profits of foreign funded enterprises. Furthermore, those foreign interests operating Joint Ventures with Chinese companies or local authorities have to share a proportion of any profits with their Chinese partners. As such, it would be rational for foreign companies operating in China to locate as much of their profits as possible in operations outside China by overcharging factories in China for imported components supplied by factories in other countries.

Figures provided by the China Association of Enterprises with Foreign Investment. Bernard, M. and Ravenhill, J. (1995) “Beyond Product Cycles and Flying Geese: Regionalization, Hierarchy, and the Industrialization of East Asia” World Politics (47): 197. Smart, A. (2002) The Hong Kong/Pearl River Delta Urban Region: An Emerging Transnational Mode of Regulation or Just Muddling Through? in John Logan (ed), The New Chinese City: Globalization and Market Reform (Oxford: Blackwell): 92-105.

Bernard. M and Ravenhill, J (1995) "Beyond Product Cycles and Flying Geese: Regionalization, Hierarchy, and the Industrialization of East Asia" World Politics (47) : 171209. Crone, R (1993) “Does Hegemony Matter? The Reorganization of the Pacific Political Economy” World Politics (45): 501-25. 

Katzenstein and Takashi Shiaishi (eds) Network Power: Japan and Asia (Ithaca: Cornell University Press) : 1-46.

Takashi Isogai, Hirofumi Morishita and Rasmus Rüffer (2002) “Analysis of Intra- and Inter-

Regional Trade in East Asia: Comparative Advantage Structures and Dynamic

Interdependency in Trade Flows” Bank of Japan International Department Working Paper

Series No. 02-E-1.

Matsuzaki, Y. (1997) "Hon Kon: tai Chu kyoten to shite no genjo" in K Ishihara (ed) Chugoku Keizai no Kokusaika to Higashi Ajia Tokyo: Ajia Keizai Kenkyusho): 160 - cited in Sasuga, Katsuhiro (2004) Microregionalism and Governance in East Asia (London: Routledge). Sasuga, Katsuhiro (2004) Microregionalism and Governance in East Asia (London: Routledge). See Borrus, M. (1995) Left for Dead: Asian Production Networks and the Revival of US Electronics,Berkeley Roundtable on the International Economy Working Paper; Borrus, M. and Zysman, J. (1997) Wintelism and the Changing Terms of Global Competition: Prototype of the Future? Berkeley Roundtable on International Economy Working Paper 96b; and Chen Shin-Hong (2002) "Global production networks and information technology: The case of Taiwan” Industry and Innovaton, 9 (3) :. 249-265. Sasuga, Katsuhiro (2004) Microregionalism and Governance in East Asia (London: Routledge). China comes third with 170. Hong Kong SAR Census and Statistics Department (2002) Annual Survey of Regional Offices Representing Overseas Companies in Hong Kong (Hong Kong: Government Information Centre). Li Qiang (2002) "Nike, Adidas, Reebok and New Balance Made in China” China Labor Watch, 25th October. State Council (1997) On Sino-US Trade Balance, Beijing: Information Office of the State Council Of the People's Republic of China, March.

Luthje, B. (2002) "Electronics contract manufacturing: Global production and the international division of labor in the age of the Internet” Industry and Innovation, 9 (3): 227247.

Rodrik, D. (1997) Has Globalization Gone too Far, (Washington DC: Institute for International Economics): 46.

Hanson, Gordon and Feenstra, Robert (2001) "Intermediaries in Entrepôt Trade: Hong Kong Re-Exports of Chinese Goods” NBER Working Paper 8088.

Hamilton, G. (1999) “Asian Business Networks in Transition: or What Alan Greenspan Does Not Know About the Asian Business Crisis” in TJ Pempel (ed) The Politics of the Asian Economic Crisis, (Ithaca: Cornell UP): 60.

Shin-Hong Chen (2002) Global production networks and information technology: The case of Taiwan; Industry and Innovation, 9 (3): 251. See also Kotabe, M (1996) "Global Sourcing Strategy In The Pacific: American And Japanese Multinational Companies”, in G. Boyd (ed), Structural Competitiveness in the Pacific. (Cheltenham: Edward Elgar); and Swamidass, P and Kotabe, M. (1993) "Component sourcing strategies of multinationals: an empirical study of European and Japanese multinationals” in Journal of International Business Studies, 24(1): 81-100.

As a percentage of all production in the global IT industry. Luthje, B. (2002) "Electronics contract manufacturing: Global production and the international division of labor in the age of the Internet” Industry and Innovation, 9 (3): 228-9.

Roach, S. (2002) “Global: China's Heavy Lifting” Morgan Stanley Global Economic Forum, $6^{\text {th }}$ March.

Kenichi Ohmae (1995) The End of the Nation State (London: Harper Collins).

Bernard, M (1996) "States, Social Forces, and Regions In Historical Time: Toward a Critical Political Economic of Eastern Asia” Third World Quarterly 17 (4) : 649-665.

Gereffi, G (1996) “Commodity Chain and Regional Divisions of Labor in East Asia” Journal of Asian Business 12 (1) pp.75-112.

Based on the works of Robert Cox. 